\title{
Annulation With and Without CO-Insertion: Striking a Balance in Reactivity of Chromium Carbene Complexes with Chalcogen-Stabilized Iron Cluster Appendage
}

\author{
Pradeep Mathur, ${ }^{\mathrm{a}, *}$ Sundargopal Ghosh, ${ }^{\mathrm{a}}$ Amitabha Sarkar, ${ }^{\mathrm{b}}$ Arnold L. Rheingold ${ }^{\mathrm{c}}$ \\ and Ilia A. Guzei ${ }^{\mathrm{C}}$ \\ ${ }^{a}$ Chemistry Department, Indian Institute of Technology, Powai, Bombay 400076, India \\ ${ }^{\mathrm{b}}$ Division of Organic Chemistry (Synthesis), National Chemical Laboratory, Pune 411008, India \\ ${ }^{\mathrm{c}}$ Department of Chemistry, University of Delaware, Newark, DE 19716, USA
}

\begin{abstract}
Two new sets of products $\left[(\mathrm{CO})_{6} \mathrm{Fe}_{2} \mathrm{EE}^{\prime}\{\mu\right.$-indanone $\left.\}\right]\left(\mathbf{2 a}: \mathrm{E}, \mathrm{E}^{\prime}=\mathrm{Se} ; \mathbf{2 b}\right.$ : $\left.\mathrm{E}=\mathrm{S}, \mathrm{E}^{\prime}=\mathrm{Se}\right)$ and $\left[(\mathrm{CO})_{6} \mathrm{Fe}_{2} \mathrm{EE}^{\prime}\{\mu-(2-\mathrm{ethoxy}\right.$, $\alpha$-naphthol)\}] (3a: $\left.\mathrm{E}, \mathrm{E}^{\prime}=\mathrm{Se} ; \mathbf{3 b}: \mathrm{E}=\mathrm{S}, \mathrm{E}^{\prime}=\mathrm{Se} ; \mathbf{3 c}: \mathrm{E}=\mathrm{S}, \mathrm{E}^{\prime}=\mathrm{Te}\right)$ have been isolated from the thermolysis of the cluster-bound Fischer carbene complex, $\left[(\mathrm{CO})_{6} \mathrm{Fe}_{2} \mathrm{EE}^{\prime}\left\{\mu-\mathrm{C}(\mathrm{Ph})=\mathrm{C}-\mathrm{C}(\mathrm{OEt})=\mathrm{Cr}(\mathrm{CO})_{5}\right\}\right], \mathbf{1 a}-\mathbf{c}\left(\mathbf{1 a}: \mathrm{E}, \mathrm{E}^{\prime}=\mathrm{Se} ; \mathbf{1 b}: \mathrm{E}=\mathrm{S}, \mathrm{E}^{\prime}=\mathrm{Se} ; \mathbf{1 c}: \mathrm{E}=\mathrm{S}, \mathrm{E}^{\prime}=\mathrm{Te}\right)$ in $\mathrm{THF}$. The products are formed by annulation pathway with and without the intermediacy of CO insertion step, from the same substrate. They have been characterized by IR and ${ }^{1} \mathrm{H},{ }^{13} \mathrm{C},{ }^{77} \mathrm{Se}$ and ${ }^{125} \mathrm{Te}$ NMR spectroscopy and the structural types were unequivocally established by crystallographic analysis of compounds $\mathbf{2 a}$ and $\mathbf{3 c}$.
\end{abstract}

\section{Introduction}

Some of the earliest information on the reactivity of the chalcogen-stabilized iron carbonyl clusters, $\left[\mathrm{Fe}_{2}(\mathrm{CO})_{6}\right.$ $\left.\left(\mu-E^{\prime}\right)\right]$ (where $E, E^{\prime}=S, S e, T e$ ) originated in studies of the reduction of carbon-carbon triple bond in terminal alkynes by the reactive chalcogen-chalcogen bonds present in $\left[\mathrm{Fe}_{2}(\mathrm{CO})_{6}\left(\mu-\mathrm{EE}^{\prime}\right)\right]$ and these iron carbonyl clusters of the same structure with compositions differing only in the identity of the main group element are very rare. ${ }^{1}$ The chalcogen-stabilized diiron compounds $\left[\mathrm{Fe}_{2}(\mathrm{CO})_{6}\left(\mu-\mathrm{EE}^{\prime}\right)\right]$ add readily to the triple bond of the carbene complexes $\left[(\mathrm{CO})_{5} \mathrm{M}=\mathrm{C}(\mathrm{OEt})(\mathrm{C} \equiv \mathrm{CPh})\right] \quad(\mathrm{M}=\mathrm{Cr}, \mathrm{W})$ to form the adducts, $\quad\left[(\mathrm{CO})_{6} \mathrm{Fe}_{2} \mathrm{EE}^{\prime}\{\mu-\mathrm{PhC}=\mathrm{CC}(\mathrm{OEt})\} \mathrm{M}(\mathrm{CO})_{5}\right] .^{2} \quad$ In those cases where $\mathrm{E} \neq \mathrm{E}^{\prime}$, such additions are highly regioselective. $^{2 \mathrm{a}}$ The Fischer carbene moiety in these adducts is a potential organic functional group, as demonstrated by its facile transformation to an amino carbene group, an ester, an orthoester $^{2 \mathrm{~b}}$ or an enol ether derivative. ${ }^{3}$

The competitive formation of benzannulation and cyclopentannulation products from the same reaction is well precedented and can be tuned e.g. by $N$-acylation. ${ }^{4}$ Our preliminary investigations indicate ${ }^{5}$ that product formation upon thermolysis is strongly influenced by the nature of chalcogen atoms present in the trimetallic adducts $\left[(\mathrm{CO})_{6} \mathrm{Fe}_{2} \mathrm{EE}^{\prime}\{\mu-\mathrm{C}(\mathrm{Ph})=\mathrm{CC}(\mathrm{OEt})\} \mathrm{Cr}(\mathrm{CO})_{5}\right]$ and such studies, including those aimed towards cyclopentannulation continue to be of significant interest as they show some exciting physical properties e.g. non linear optical activity, NLO. ${ }^{6}$ Thus, when thermolysis of $\left[(\mathrm{CO})_{6} \mathrm{Fe}_{2} \mathrm{STe}\right.$ $\left.\{\mu-\mathrm{PhC}=\mathrm{CC}(\mathrm{OEt})\} \mathrm{Cr}(\mathrm{CO})_{5}\right]$ was carried out, no cyclopentannulation was observed; two compounds were isolated and identified as $\left[(\mathrm{CO})_{6} \mathrm{Fe}_{2}\{\mu-\mathrm{SC}(\mathrm{Ph})=\mathrm{C}(\mathrm{Te})-\mathrm{C}(\mathrm{H})\right.$ $(\mathrm{OEt})\}]_{2}$ and $\left[(\mathrm{CO})_{6} \mathrm{Fe}_{2}\{\mu-\mathrm{SC}(\mathrm{H})(\mathrm{Ph})-\mathrm{C}(\mathrm{Te})=\mathrm{C}(\mathrm{H})\right.$ (OEt) $\}]{ }^{5 b}$ Since the amount of isolated products did not provide a satisfactory material balance, the reaction mixture was closely examined for identification of more polar components and here we report the results of an investigation of the thermolysis of $\left[(\mathrm{CO})_{6} \mathrm{Fe}_{2} \mathrm{EE}^{\prime}\{\mu-\mathrm{C}(\mathrm{Ph})=\mathrm{CC}\right.$ $\left.\left.(\mathrm{OEt})=\mathrm{Cr} \quad(\mathrm{CO})_{5}\right\}\right]$, 1a-c $\quad\left(\mathbf{1 a}: \mathrm{E}, \mathrm{E}^{\prime}=\mathrm{Se} ; \mathbf{1 b}: \mathrm{E}=\mathrm{S}\right.$, $\mathrm{E}^{\prime}=\mathrm{Se}$; 1c: $\mathrm{E}=\mathrm{S}, \mathrm{E}^{\prime}=\mathrm{Te}$ ) with a focus on the isolation of more polar compounds.

\section{Results and Discussion}

Thermolysis of complexes $\left[(\mathrm{CO})_{6} \mathrm{Fe}_{2} \mathrm{EE}^{\prime}\{\mu-\mathrm{C}(\mathrm{Ph})=\mathrm{CC}\right.$ $\left.\left.(\mathrm{OEt})=\mathrm{Cr}(\mathrm{CO})_{5}\right\}\right], \mathbf{1 a}-\mathbf{c}\left(\mathbf{1 a}: \mathrm{E}, \mathrm{E}^{\prime}=\mathrm{Se} ; \mathbf{1 b}: \mathrm{E}=\mathrm{S}, \mathrm{E}^{\prime}=\mathrm{Se}\right.$; 1c: $\mathrm{E}=\mathrm{S}, \mathrm{E}^{\prime}=\mathrm{Te}$ ) was carried out under previously reported condition (THF reflux, $3 \mathrm{~h}$ ). Chromatographic work-up using a polar solvent system of $\mathrm{CH}_{2} \mathrm{Cl}_{2} /$ hexane $(40: 60 \mathrm{v} / \mathrm{v})$ for elution afforded two new complexes: $\left[(\mathrm{CO})_{6} \mathrm{Fe}_{2} \mathrm{EE}^{\prime}\{\mu\right.$ indanone $\}$ (2a: $\left.\mathrm{E}, \mathrm{E}^{\prime}=\mathrm{Se} ; \mathbf{2 b}: \mathrm{E}=\mathrm{S}, \mathrm{E}^{\prime}=\mathrm{Se}\right)$ and $\left[(\mathrm{CO})_{6} \mathrm{Fe}_{2} \mathrm{EE}^{\prime}\{\mu\right.$-(2-ethoxy, $\alpha$-naphthol $\left.\left.)\right\}\right]\left(3 \mathbf{a}: \mathrm{E}, \mathrm{E}^{\prime}=\mathrm{Se}\right.$; 


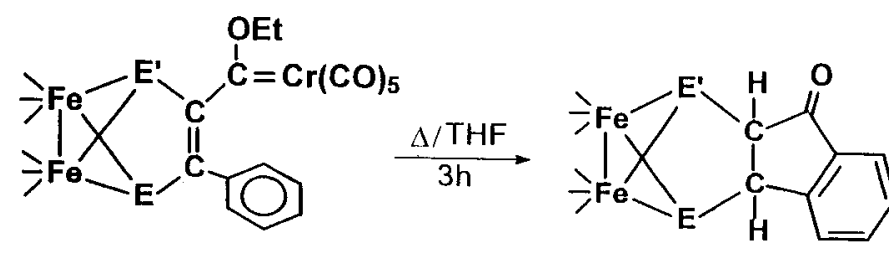

1a-c 2a: $E_{,} E^{\prime}=S e$

2b: $E=S, E^{\prime}=S e$<smiles>CCOc1c2c(c3ccccc3c1O)C1(C)C(C)(C)C(C)(C)C1(C)C2</smiles>

3a: $E, E^{\prime}=S e$

3b: $E=S, E^{\prime}=S e$ $3 c: E=S, E^{\prime}=T e$

Scheme 1.

3b: $\left.E=S, E^{\prime}=S e ; 3 c: E=S, E^{\prime}=T e\right)($ Scheme 1). These products were characterized by their spectral characteristics and crystal structure determination of representative complexes 2a and 3c. When the thermolysis reaction of complexes 1a-c was carried out in toluene at $85^{\circ} \mathrm{C}$, formation of $\alpha$-naphthol derivatives, $\mathbf{3 a}-\mathbf{c}$ predominates. The thermolysis of 1a gives better yield of the $\alpha$-naphthol derivative, 3a $(70 \%)$ than the thermolysis of $\mathbf{1 b}$ and $\mathbf{1 c}$ (3b: 34\%; 3c: 38\%) (Scheme 1).

The IR spectra of compounds $\mathbf{2 a}$ and $\mathbf{2 b}$ showed signals corresponding to the presence of the terminally bonded metal carbonyl groups and a band at $1727 \mathrm{~cm}^{-1}$ due to a ketonic carbonyl function. The high value of the ketone carbonyl absorption suggested the presence of a fivemembered ketone unit in this molecule. ${ }^{7}$ The ${ }^{1} \mathrm{H}$ NMR spectra showed typical sets of doublets associated with Se satellites, i.e. the carbon bearing these protons are attached to a selenium atom. The ${ }^{13} \mathrm{C}$ NMR spectra displayed a downfield signal for the $\mathrm{Fe}-\mathrm{CO}$ groups at $209 \mathrm{ppm}$. Two peaks were observed for the saturated carbon atoms in complexes $\mathbf{2 a}$ and $\mathbf{2 b}$; the deshielded signals are assigned to the carbons adjacent to the ketone whose presence was confirmed by the signal at $\delta 199.3(\mathbf{2 a})$ and $198.1(\mathbf{2 b}) \mathrm{ppm}$. For complex 2a, the ${ }^{77} \mathrm{Se}$ NMR spectrum showed two signals. The downfield signal is a doublet with $J_{\mathrm{Se}-\mathrm{H}}$ of $19.8 \mathrm{~Hz}$ and the upfield signal is a doublet of doublet with $J_{\mathrm{Se}-\mathrm{H}}=25.9 \mathrm{~Hz}$. One doublet signal was observed with $J_{\mathrm{Se}-\mathrm{H}}$ of $18.3 \mathrm{~Hz}$ for complex $\mathbf{2} \mathbf{b}$.

Yellow crystals of 2a were grown from hexane solvent at $-4^{\circ} \mathrm{C}$ and a single crystal $\mathrm{X}$-ray diffraction analysis was carried out. Its molecular structure is shown in Fig. 1.

The structure can best be described as consisting of an open $\mathrm{Fe}_{2}(\mathrm{CO})_{6} \mathrm{Se}_{2}$ unit with an indanone moiety formally inserted between the two Se atoms. The distance between the two carbon atoms $[C(7)$ and $C(15)]$ which are attached to the selenium atoms, is slightly longer $(1.502(6) \AA)$ than the analogous $\mathrm{C}-\mathrm{C}$ bond distance of $1.48(1) \AA$, observed in a previously reported double butterfly cluster $\left[\left\{(\mathrm{CO})_{6} \mathrm{Fe}_{2}(\mu\right.\right.$ $\left.\left.\mathrm{Se})_{2}\right\}_{2} \mathrm{C}(\mathrm{Ph})-\mathrm{C}(\mathrm{H})\right],{ }^{8}$ and the analogous $\mathrm{C}-\mathrm{C}$ bond distance of $1.47(2)(\AA)$ in the enol ether derivative $\left[(\mathrm{CO})_{6} \mathrm{Fe}_{2}\{\mu\right.$ $\mathrm{SC}(\mathrm{H}) \mathrm{Ph}-\mathrm{C}(\mathrm{Te})=\mathrm{C}(\mathrm{H})(\mathrm{OEt})\}]^{3}$. The two $\mathrm{C}-\mathrm{Se}$ bond distances in compound $\mathbf{2 a}$ are nearly equal.

The IR spectra of compound $\mathbf{3 a}-\mathbf{c}$ showed typical peaks for terminally bonded metal-CO groups. The ${ }^{1} \mathrm{H}$ NMR spectra of compounds $3 \mathbf{a}-\mathbf{c}$ featured a sharp singlet in the region $\delta$ 6.1-6.2 ppm, which was exchangeable with $\mathrm{D}_{2} \mathrm{O}$ and consequently was assigned to the phenolic hydroxyl group. The ${ }^{13} \mathrm{C}$ NMR spectra displayed six aromatic quaternary carbon peaks and four aromatic carbon atoms bearing a hydrogen each between $\delta 113.2$ and $143.2 \mathrm{ppm}$.

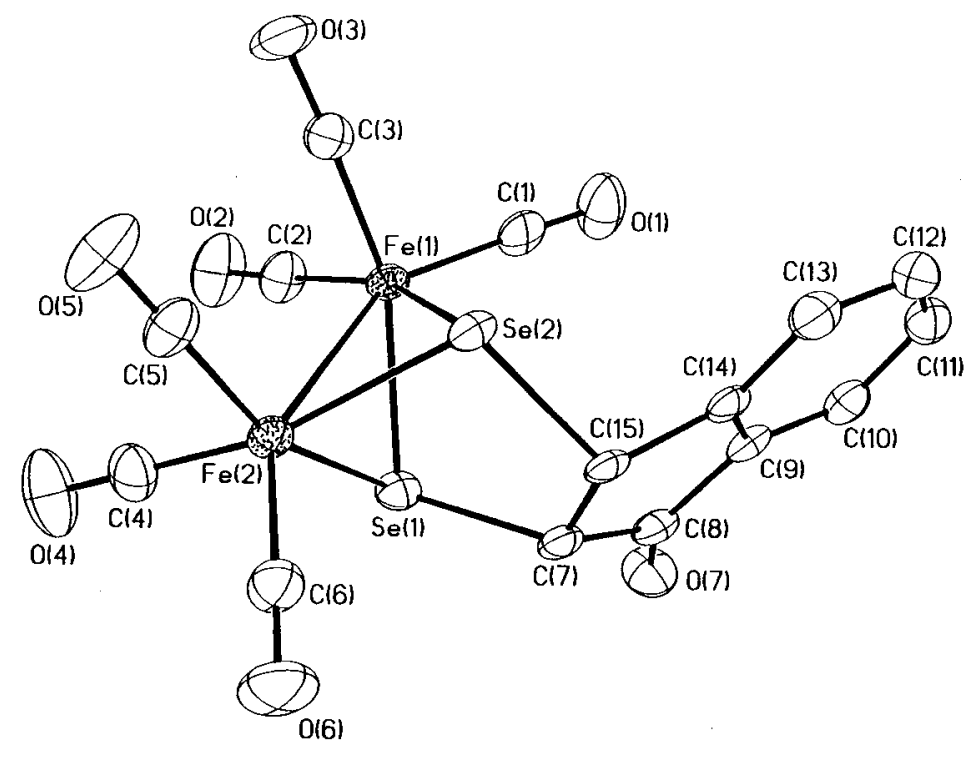

Figure 1. $\left[(\mathrm{CO})_{6} \mathrm{Fe}_{2} \mathrm{Se}_{2}\{\mu\right.$-indanone $\left.\}\right]$ (2a). 


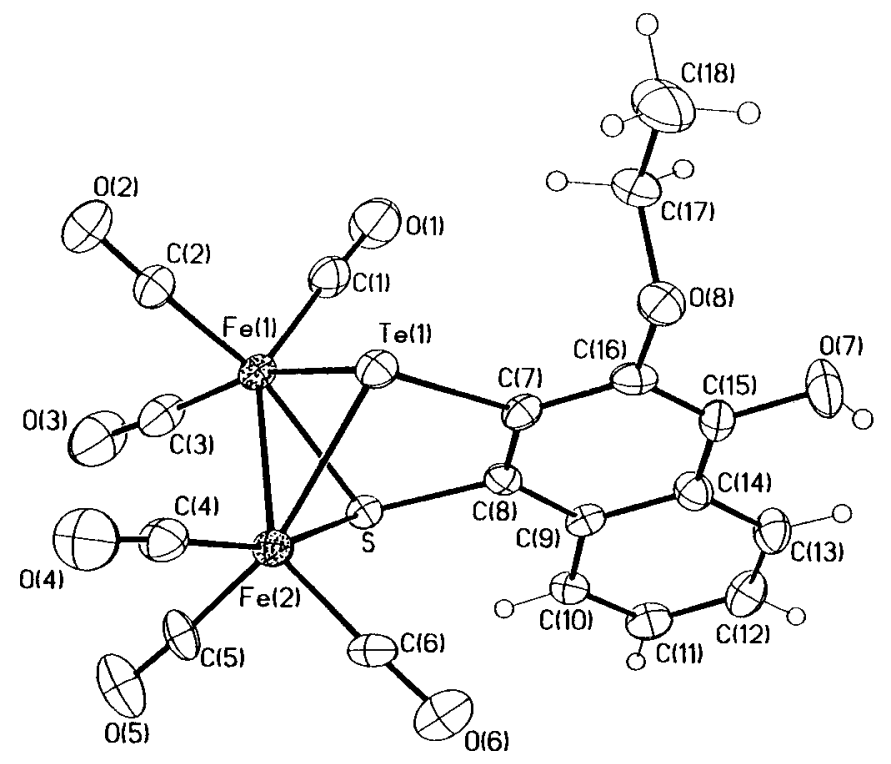

Figure 2. $\left[(\mathrm{CO})_{6} \mathrm{Fe}_{2} \mathrm{STe}\{\mu\right.$-(2-ethoxy, $\alpha$-naphthol) $\left.\}\right]$ (3c).

The ${ }^{77}$ Se NMR spectrum showed two expected singlets for 3a and one singlet for 3b. Similarly, the ${ }^{125}$ Te NMR spectrum of compound $\mathbf{3 c}$ featured a single peak. An unambiguous assignment of these two isostructural complexes was made on the basis of crystal structure determination of complex $\mathbf{3 c}$.

Red crystals of $3 \mathbf{c}$ were grown from hexane $/ \mathrm{CH}_{2} \mathrm{Cl}_{2}$ at $0^{\circ} \mathrm{C}$ and a single crystal $\mathrm{X}$-ray diffraction analysis was carried out. Its molecular structure is shown in Fig. 2. A naphthol ring attached to the chalcogen atoms of $\mathrm{Fe}_{2} \mathrm{STe}$ butterfly core was observed. The olefinic bond distance of $1.346(11) \AA$ in 3c [C(7) and C(8)] attached with the chalcogen atoms, is comparable to the olefinic bond distance of $1.36 \AA$ in the uncoordinated naphthol ring. No appreciable deviation from planarity was observed with its $\mathrm{S}$ and $\mathrm{Te}$ substituents (dihedral angles: $\mathrm{Te}-\mathrm{C}(7)-\mathrm{C}(8)-\mathrm{C}(9)=8.7^{\circ}$; $\mathrm{S}-\mathrm{C}(8)-\mathrm{C}(7)-\mathrm{C}(16)=2.2^{\circ}$ and $\mathrm{Te}-\mathrm{C}(7)-\mathrm{C}(16)-\mathrm{O}(8)=$ $\left.6.3^{\circ}\right)$. This angularly fused polycyclic structure can be viewed as an unusual, organometallic analog of phenanthrene with a sulfur atom in the 'bay' region. The position of the sulfur atom also suggests that, with appropriate metal ion, it can lead to an ortho-metallated complex involving the $\mathrm{C}(10)$ center. $^{9}$

Formation of these products, $\mathbf{2 a}-\mathbf{b}$ and $\mathbf{3 a}-\mathbf{c}$ can be explained by involving steps well-precedented in metalcarbene chemistry ${ }^{10}$ where the cis-olefinic bond makes the annulation reactions readily attainable. Two product sets, 2 and $\mathbf{3}$ probably result from two alternative pathways-one involves $\mathrm{CO}$ insertion step (leading to $\mathbf{3 a} \mathbf{a}-\mathbf{c}$ ) while the other does not (leading to $\mathbf{2} \mathbf{a}$ and $\mathbf{2 b}$ ). It is interesting to note that the same substrate can react via both these pathways at the same time albeit with different rates. This suggests that the electron density on the chromium metal in complexes 1a-c lies somewhere in between usual alkoxy and amino carbene complexes of chromium. ${ }^{11}$ It is indeed a rare instance that the same carbene complex gives rise to two different products in the same reaction. ${ }^{12}$

Moreover, the transformation from $1 \mathbf{a}-\mathbf{c}$ to $\mathbf{3 a}-\mathbf{c}$ belongs to a unique class of reactions where an annulation occurs from a cis-cinnamyl chromium carbene derivative without the requirement of an added alkyne, and the product is a vicinally dioxygenated product. Examples of such transformation are rare and the only example known is a photoinduced one. ${ }^{13}$ It is significant that the irradiation of substrate 1a with $400 \mathrm{~W}$ medium pressure mercury lamp with a Pyrex filter for $6 \mathrm{~h}$ failed to produce a noticeable change in the starting complex, though the thermal reaction is comparatively facile, and in this respect, curiously enough, our reaction differs from that reported by Merlic. ${ }^{13}$

\section{Experimental}

\section{General}

All reactions and other manipulations were carried out under an argon or nitrogen atmosphere, using standard Schlenk techniques. Solvents were deoxygenated immediately prior to use. Reactions were monitored by FT-IR spectroscopy and thin-layer chromatography. Infrared spectra were recorded on a Nicolet-Impact 400 FT-IR spectrometer as $n$-hexane solutions in sodium chloride cell at $0.1 \mathrm{~mm}$ path length.

Photolysis reaction was done in $400 \mathrm{~W}$ medium pressure mercury vapor lamp using Pyrex filter. Elemental analyses were performed using a Carlo Erba 1106 automatic analyzer. ${ }^{1} \mathrm{H},{ }^{13} \mathrm{C},{ }^{77} \mathrm{Se}$ and ${ }^{125} \mathrm{Te}$ NMR spectra were recorded on a Varian VXR 300S spectrometer in $\mathrm{CDCl}_{3}$ at $25^{\circ} \mathrm{C}$. The operating frequency for ${ }^{77} \mathrm{Se} \mathrm{NMR}$ was $57.23 \mathrm{MHz}$ with a pulse width of $15 \mu \mathrm{s}$ and a delay of $1.0 \mathrm{~s}$ and operating frequency for ${ }^{125} \mathrm{Te}$ was $94.70 \mathrm{MHz}$ with pulse width of $9.5 \mu \mathrm{s}$ and a delay of $1 \mathrm{~s} .{ }^{77} \mathrm{Se}$ NMR spectra were referenced to $\mathrm{Me}_{2} \mathrm{Se}(\delta=0 \mathrm{ppm})$ and ${ }^{125} \mathrm{Te}$ NMR spectra were referenced to $\mathrm{Me}_{2} \mathrm{Te}(\delta=0 \mathrm{ppm})$.

Chromium hexacarbonyl, phenylacetylene and THF- $d 8$ were purchased from Aldrich Chemical Co., and these 
Table 1. Crystallographic data for $\mathbf{2 a}$ and $\mathbf{3 c}$

\begin{tabular}{|c|c|c|}
\hline & $2 \mathbf{a}$ & $3 c$ \\
\hline Formula & $\mathrm{C}_{15} \mathrm{H}_{6} \mathrm{Fe}_{2} \mathrm{O}_{7} \mathrm{Se}_{2}$ & $\mathrm{C}_{18} \mathrm{H}_{10} \mathrm{Fe}_{2} \mathrm{O}_{8} \mathrm{STe}$ \\
\hline Formula weight & 567.82 & 625.62 \\
\hline Space group & $P \bar{l}$ & $P 2_{1} / n$ \\
\hline$a, \AA$ & $9.086(2)$ & $6.793(2)$ \\
\hline$b, \AA$ & $9.202(2)$ & $21.348(14)$ \\
\hline$c, \AA$ & $11.765(3)$ & $14.579(6)$ \\
\hline$\alpha,{ }^{\circ}$ & $80.49(2)$ & - \\
\hline$\beta,{ }^{\circ}$ & $70.79(2)$ & $96.73(4)$ \\
\hline$\gamma, \circ$ & $78.738(13)$ & - \\
\hline$V, \AA^{3}$ & $905.6(3)$ & $2100(2)$ \\
\hline$Z$ & 2 & 4 \\
\hline Crystal color, Habit & Red block & Red plate \\
\hline$D$ (calc), $\mathrm{g} / \mathrm{cm}^{3}$ & 2.082 & 1.979 \\
\hline$\mu(\mathrm{MoK} \alpha), \mathrm{cm}^{-1}$ & 56.54 & 28.85 \\
\hline Temp, K & 293(2) & 293(2) \\
\hline Absorption-correction & Empirical & - \\
\hline$T(\max ) / T(\min )$ & $1.000 / 0.549$ & - \\
\hline Diffractometer & \multicolumn{2}{|c|}{ Siemens P4 } \\
\hline Radiation $(\lambda=0.71073 \AA)$ & \multicolumn{2}{|c|}{$\operatorname{MoK} \alpha$} \\
\hline$R(F), \%^{\mathrm{a}}$ & 2.58 & 4.52 \\
\hline$R\left(w F^{2}\right), \%^{\mathrm{a}}$ & 5.57 & 10.97 \\
\hline
\end{tabular}

${ }^{a}$ Quantity minimized $=R\left(w F^{2}\right)=\sum\left[w\left(F_{\mathrm{o}}^{2}-F_{\mathrm{c}}^{2}\right)^{2}\right] / \sum\left[\left(w F_{\mathrm{o}}^{2}\right)^{2}\right]^{1 / 2} ; R=$ $\sum \Delta / \sum\left(F_{\mathrm{o}}\right), \Delta=\left|\left(F_{\mathrm{o}}-F_{\mathrm{c}}\right)\right|$.

were used without further purification. The homo- and mixed-chalcogenide iron carbonyl clusters $\mathrm{Fe}_{2}(\mu$ $\left.\mathrm{Se}_{2}\right)(\mathrm{CO})_{6},{ }^{14} \mathrm{Fe}_{2}(\mu-\mathrm{SSe})(\mathrm{CO})_{6}{ }^{15}$ and $\mathrm{Fe}_{2}(\mu-\mathrm{STe})(\mathrm{CO})_{6}{ }^{16}$ $\alpha, \beta$ unsaturated mixed chalcogenide carbene complexes $\left[(\mathrm{CO})_{6} \mathrm{Fe}_{2} \mathrm{EE}^{\prime}\left\{\mu-\mathrm{C}(\mathrm{Ph})=\mathrm{C}-\mathrm{C}(\mathrm{OEt})=\mathrm{Cr}(\mathrm{CO})_{5}\right\}\right],(\mathbf{1 a}: \mathrm{E}$, $\left.\mathrm{E}^{\prime}=\mathrm{Se} ; \mathbf{1 b}: \mathrm{E}=\mathrm{S}, \mathrm{E}^{\prime}=\mathrm{Se} ; \mathbf{1 c}: \mathrm{E}=\mathrm{S}, \mathrm{E}^{\prime}=\mathrm{Te}\right)^{2}$ and the alkynyl Fischer carbene complexes $\left[(\mathrm{CO})_{5} \mathrm{M}=\mathrm{C}(\mathrm{OEt})(\mathrm{C} \equiv \mathrm{CPh})\right]^{17}$ $(\mathrm{M}=\mathrm{Cr}, \mathrm{W})$ were prepared as previously reported.

\section{General procedure for themolysis of $\left[(\mathrm{CO})_{6} \mathrm{Fe}_{2} \mathrm{EE}^{\prime}\right.$ $\left.\left\{\mu-\mathrm{C}(\mathrm{Ph})=\mathrm{CC}(\mathrm{OEt})=\mathrm{Cr}(\mathrm{CO})_{5}\right\}\right]\left(1 \mathrm{a}: \mathrm{E}, \mathrm{E}^{\prime}=\mathrm{Se}\right.$; 1b: $\mathbf{E}=S, E^{\prime}=$ Se; 1c: $\left.E=S, E^{\prime}=T e\right)$}

A solution of $\left[(\mathrm{CO})_{6} \mathrm{Fe}_{2} \mathrm{EE}^{\prime}\{\mu-\mathrm{C}(\mathrm{Ph})=\mathrm{CC}(\mathrm{OEt})=\mathrm{Cr}\right.$ $\left.\left.(\mathrm{CO})_{5}\right\}\right],\left(1 \mathbf{a}: \mathrm{E}, \mathrm{E}^{\prime}=\mathrm{Se} ; \mathbf{1 b}: \mathrm{E}=\mathrm{S}, \mathrm{E}^{\prime}=\mathrm{Se} ; 1 \mathbf{c}: \mathrm{E}=\mathrm{S}\right.$, $\left.\mathrm{E}^{\prime}=\mathrm{Te}\right)$ in THF $(10 \mathrm{~mL})$ was heated at $85^{\circ} \mathrm{C}$ for $3 \mathrm{~h}$. The reaction was monitored by TLC, and stopped when all the starting material was consumed. The solution was filtered through Celite to remove the insoluble materials. After removal of solvent from the filtrate, the residue was subjected to chromatographic work-up using silica gel TLC plates. Elution with hexane/ $\mathrm{CH}_{2} \mathrm{Cl}_{2}$ (40:60) mixture afforded two polar complexes, in order of polarity: yellow $\left[(\mathrm{CO})_{6} \mathrm{Fe}_{2} \mathrm{EE}^{\prime}\{\mu\right.$-indanone $\left.\}\right]$ (2a: $\mathrm{E}$, $\left.\mathrm{E}^{\prime}=\mathrm{Se} ; 2 \mathbf{b}: \mathrm{E}=\mathrm{S}, \mathrm{E}^{\prime}=\mathrm{Se}\right)$ and red $\left[(\mathrm{CO})_{6} \mathrm{Fe}_{2} \mathrm{EE}^{\prime}\{\mu-(2-\right.$ ethoxy, $\alpha$-naphthol) \}] (3a: E, $\mathrm{E}^{\prime}=\mathrm{Se} ; \mathbf{3 b}$ : $\mathrm{E}=\mathrm{S}, \mathrm{E}^{\prime}=\mathrm{Se} ; \mathbf{3 c}$ : $\left.\mathrm{E}=\mathrm{S}, \mathrm{E}^{\prime}=\mathrm{Te}\right)$.

2a: yield 15\%. IR: 2072 (s), 2036 (vs), 2003 (s), 1998 (s), $1984(\mathrm{w}), 1728(\mathrm{~m}) ;{ }^{1} \mathrm{H}$ NMR: $\delta 4.06\left(1 \mathrm{H}, \mathrm{d}, J_{\mathrm{H}^{-}{ }_{\mathrm{H}}}=6.2 \mathrm{~Hz}\right.$, $\left.J_{\mathrm{Se}-\mathrm{H}}=19.8 \mathrm{~Hz},(\mathrm{CO}) \mathrm{CH}\right), 4.95\left(1 \mathrm{H}, \mathrm{d}, J_{\mathrm{H}^{-} \mathrm{H}}=6.1 \mathrm{~Hz}\right.$, $\left.J_{\mathrm{Se}-\mathrm{H}}=25.8 \mathrm{~Hz}, \mathrm{CCH}\right), 7.4-7.7\left(4 \mathrm{H}, \mathrm{m}, \mathrm{C}_{6} H_{5}\right) ;{ }^{13} \mathrm{C} \mathrm{NMR}$ : $\delta 48.3\left(\mathrm{SeCH}(\mathrm{Ph}), J_{\mathrm{C}-\mathrm{H}}=154.9 \mathrm{~Hz}\right), 54.5(\mathrm{SeCH}(\mathrm{CO})$, $\left.J_{\mathrm{C}-\mathrm{H}}=150.2 \mathrm{~Hz}\right), 124.4,126.4,129.7,136.6(4 \mathrm{CH}$, in indanone ring), 133.4, 152.8 (quat $C$ in indanone ring), $199\left(\mathrm{CO}\right.$, in indanone ring), $208.6\left\{\left(\mathrm{Fe}(\mathrm{CO})_{3}\right\} ;{ }^{77} \mathrm{Se}\right.$ NMR: $\delta 618\left\{\mathrm{dd}, J_{\mathrm{Se}-\mathrm{H}}=25.9\right.$ and $\left.2.3 \mathrm{~Hz}, \mathrm{SeC}(\mathrm{H}) \mathrm{C}\right\}, 636$ $\left\{\mathrm{d}, J_{\mathrm{Se}-\mathrm{H}}=19.1 \mathrm{~Hz}, \mathrm{SeC}(\mathrm{H})(\mathrm{CO})\right\} ; \mathrm{mp}: 162-164^{\circ} \mathrm{C}$ Anal. calcd (Found) for $\mathrm{Fe}_{2} \mathrm{Se}_{2} \mathrm{C}_{15} \mathrm{O}_{7} \mathrm{H}_{6}: \mathrm{C}, 31.7$ (31.9), H, 1.05 (1.09).

3a: yield 18\%. IR: 2071 (s), 2035 (vs), 2001 (s), 1985 (w), 1951 (w); ${ }^{1} \mathrm{H}$ NMR: $\delta 1.55\left(3 \mathrm{H}, \mathrm{t}, J=6.9 \mathrm{~Hz}, \mathrm{CH}_{3}\right), 4.12$ $\left(2 \mathrm{H}, \mathrm{q}, J=7.1 \mathrm{~Hz}, \mathrm{OCH}_{2}\right), 6.09(1 \mathrm{H}, \mathrm{s},-\mathrm{OH}), 7.79-7.98$ ( $2 \mathrm{H}$, two sets of doublets, naphthol ring), 7.44-7.32 (3H, m, naphthol ring); ${ }^{13} \mathrm{C}$ NMR: $\delta 15.5\left(J_{\mathrm{C}-\mathrm{H}}=127.4 \mathrm{~Hz}, \mathrm{CH}_{3}\right)$, $71.6\left(J_{\mathrm{C}-\mathrm{H}}=140 \mathrm{~Hz}, \mathrm{OCH}_{2}\right), 122.6,125.9,126.9,127.2$ (CH carbons in naphthol ring), 113.2, 123.6, 130.3, 135.8, 140.4, 143.1 (quat carbons in naphthol ring), 208.7 $\left\{\left(\mathrm{Fe}(\mathrm{CO})_{3}\right\} ;{ }^{77} \mathrm{Se}\right.$ NMR: $\delta 353$ and $358 \mathrm{ppm}$; mp: $126-$ $128^{\circ} \mathrm{C}$ Anal. calcd (Found) for $\mathrm{Fe}_{2} \mathrm{Se}_{2} \mathrm{C}_{18} \mathrm{O}_{8} \mathrm{H}_{10}$ : C, 34.6 (34.9), H, 1.60 (1.79).

2b: yield 11\%. IR: 2075 (s), 2038 (vs), 2005 (s), 1987 (s), $1727(\mathrm{~m}) ;{ }^{1} \mathrm{H}$ NMR: $\delta 4.01\left(1 \mathrm{H}, \mathrm{d}, J=6 \mathrm{~Hz}, J_{\mathrm{Se}-\mathrm{H}}=\right.$ $18.4 \mathrm{~Hz}, \mathrm{SeC} H), 4.63(1 \mathrm{H}, \mathrm{d}, J=6.1 \mathrm{~Hz}, \mathrm{SCH}), 7.44-$ $7.75\left(4 \mathrm{H}, \mathrm{m}, \mathrm{C}_{6} H_{5}\right) ;{ }^{13} \mathrm{C}$ NMR: $\delta 52.6\left(J_{\mathrm{C}-\mathrm{H}}=152.9 \mathrm{~Hz}\right.$, $\mathrm{SeCH}(\mathrm{Ph})), 57.2 \quad\left(J_{\mathrm{C}-\mathrm{H}}=149.1 \mathrm{~Hz}, \mathrm{SCH}(\mathrm{CO})\right), 124.4$, $126.5,130.1,136.6(4 C \mathrm{H}$, in indanone ring), 134.4, 152.1 (quat $C$ in indanone ring), 198.2 ( $C \mathrm{O}$, in indanone ring), $208.2\left\{\left(\mathrm{Fe}(\mathrm{CO})_{3}\right\} .{ }^{77} \mathrm{Se} \mathrm{NMR}: \delta 712\left(\mathrm{~d}, J_{\mathrm{Se}-\mathrm{H}}=18.3 \mathrm{~Hz}\right)\right.$; mp: $156-158^{\circ} \mathrm{C}$ Anal. calcd (Found) for $\mathrm{Fe}_{2} \mathrm{SSeC}_{15} \mathrm{O}_{7} \mathrm{H}_{6}$ : $\mathrm{C}$, 34.5 (34.9), H, 1.15 (1.29).

3b: yield 23\%. IR: 2073 (s), 2039 (vs), 2001 (s), 1955 (w); ${ }^{1} \mathrm{H}$ NMR: $\delta 1.43\left(3 \mathrm{H}, \mathrm{t}, J=6.9 \mathrm{~Hz}, \mathrm{CH}_{3}\right), 4.11(2 \mathrm{H}, \mathrm{q}$, $\left.J=7.1 \mathrm{~Hz}, \mathrm{OCH}_{2}\right), 6.18(1 \mathrm{H}, \mathrm{s},-\mathrm{OH}), 7.29-7.42(5 \mathrm{H}, \mathrm{m}$, $\left.\mathrm{C}_{6} H_{5}\right), 7.87-7.95(2 \mathrm{H}$, two sets of doublets, naphthol ring),; ${ }^{13} \mathrm{C}$ NMR: $\delta 15.6\left(J_{\mathrm{C}-\mathrm{H}}=126.2 \mathrm{~Hz}, \mathrm{CH}_{3}\right), 71.6\left(J_{\mathrm{C}-\mathrm{H}}=\right.$ $\left.141.3 \mathrm{~Hz}, \mathrm{OCH}_{2}\right), 122.5,125.1,126.1,127.1(\mathrm{CH}$ carbons in naphthol ring), 123.6, 130.5, 134.2, 138.1, 139.9, 142.1 (quat carbon atoms in naphthol ring), 208.1 $\left\{\left(\mathrm{Fe}(\mathrm{CO}){ }_{3}\right\} .{ }^{77} \mathrm{Se}\right.$ NMR: $\delta 458 \mathrm{ppm} ; \mathrm{mp} 122-124^{\circ} \mathrm{C}$. Anal. calcd (Found) for $\mathrm{Fe}_{2} \mathrm{SSe}_{18} \mathrm{O}_{8} \mathrm{H}_{10}$ : C, 37.5 (37.7), $\mathrm{H}, 1.73$ (1.86).

3c: yield 21\%. IR: 2068 (s), 2034 (vs), 2000 (s), 1994 (s), $1986(\mathrm{w}), 1943(\mathrm{w}) ;{ }^{1} \mathrm{H}$ NMR: $\delta 1.48(3 \mathrm{H}, \mathrm{t}, J=6.9 \mathrm{~Hz}$, $\left.\mathrm{CH}_{3}\right), 4.08\left(2 \mathrm{H}, \mathrm{q}, J=7.1 \mathrm{~Hz}, \mathrm{OCH}_{2}\right), 6.00(1 \mathrm{H}, \mathrm{s},-\mathrm{OH})$, 7.32-7.99 (5H, m, $\left.\mathrm{C}_{6} H_{5}\right)$; ${ }^{13} \mathrm{C}$ NMR: $\delta 15.6\left(J_{\mathrm{C}-\mathrm{H}}=\right.$ $\left.127.4 \mathrm{~Hz}, \mathrm{CH}_{3}\right), 71.8\left(J_{\mathrm{C}-\mathrm{H}}=140 \mathrm{~Hz}, \mathrm{OCH}_{2}\right), 122.4$, 125.7, 126.2, 127.1 ( $\mathrm{CH}$ carbons in naphthol ring), 116.2, 124.4, 132, 142.3, 142.5, 144.9 (quat carbons in naphthol ring), $209.2\left\{\left(\mathrm{Fe}(\mathrm{CO})_{3}\right\} ;{ }^{125} \mathrm{Te} \mathrm{NMR}: \delta 515 \mathrm{ppm} ; \mathrm{mp}\left({ }^{\circ} \mathrm{C}\right)\right.$ : 128-130; Anal. calcd (Found) for $\mathrm{Fe}_{2} \mathrm{STeC}_{18} \mathrm{O}_{8} \mathrm{H}_{10}$ : C, 34.5 (34.7), H, 1.59 (1.76).

\section{General procedure for thermolysis of $\left[(\mathrm{CO})_{6} \mathrm{Fe}_{2} \mathrm{EE}^{\prime}\right.$ $\left.\left\{\mu-\mathrm{C}(\mathrm{Ph})=\mathrm{CC}(\mathrm{OEt})=\mathrm{Cr}(\mathrm{CO})_{5}\right\}\right](1 \mathrm{a}-\mathrm{c})$ in toluene}

A solution of $\left[(\mathrm{CO})_{6} \mathrm{Fe}_{2} \mathrm{EE}^{\prime}\{\mu-\mathrm{C}(\mathrm{Ph})=\mathrm{C}-\mathrm{C}(\mathrm{OEt})=\mathrm{Cr}\right.$ $\left.\left.(\mathrm{CO})_{5}\right\}\right](\mathbf{1 a}-\mathbf{c})$ in toluene $(15 \mathrm{~mL})$ was refluxed for $3 \mathrm{~h}$ and the solution was filtered through Celite to remove the insoluble materials. After removal of solvent from the filtrate, the residue was subjected to chromatographic work-up using silica gel TLC plates. Elution with hexane/ $\mathrm{CH}_{2} \mathrm{Cl}_{2}$ (40:60) mixture afforded a red band of $\left[(\mathrm{CO})_{6} \mathrm{Fe}_{2} \mathrm{EE}^{\prime}\{\mu\right.$-(2 ethoxy, $\alpha$ napthol $\left.\left.)\right\}\right]$ (3a: $\mathrm{E}, \mathrm{E}^{\prime}=\mathrm{Se}$ (70\%); 3b: $\mathrm{E}=\mathrm{S}, \mathrm{E}^{\prime}=\mathrm{Se}(34 \%) ; 3 \mathbf{c}: \mathrm{E}=\mathrm{S}, \mathrm{E}^{\prime}=\mathrm{Te}(38 \%)$ ). 
Table 2. Selected bond distances $[\AA]$ and bond angles $\left[{ }^{\circ}\right]$ for $\mathbf{2 a}$

\begin{tabular}{lllc}
\hline Fe (1)-Fe (2) & $2.5442(10)$ & Fe (2)-Se (1) & $2.3477(11)$ \\
Fe (1)-Se (2) & $2.3465(9)$ & Se (1)-C (7) & $1.981(4)$ \\
Fe (1)-Se (1) & $2.3473(10)$ & Se (2)-C (15) & $1.993(4)$ \\
Fe (2)-Se (2) & $2.3594(10)$ & C (7)-C (15) & $1.502(6)$ \\
& & & \\
Fe (1)-Fe (2)-Se(1) & $57.18(3)$ & Fe (1)-Se (1)-C(7) & $104.03(13)$ \\
Fe (2)-Fe (1)-Se(2) & $57.52(3)$ & Se (1)-C (7)-C (15) & $113.8(3)$ \\
Fe (1)-Se (2)-Fe(2) & $65.45(3)$ & Fe (2)-Se (2)-C $(15)$ & $101.86(14)$ \\
Fe (2)-Se (1)-Fe(1) & $65.63(3)$ & Fe (1)-Se (2)-C (15) & $103.00(13)$ \\
Se (2)-Fe (1)-Se(1) & $82.36(3)$ & Se (1)-C (7)-C (8) & $107.8(3)$ \\
Se (2)-Fe (2)-Se(1) & $82.08(3)$ & Se (2)-C (15)-C (14) & $110.4(3)$ \\
\hline
\end{tabular}

\section{Photolysis of $\left[(\mathrm{CO})_{6} \mathrm{Fe}_{2} \mathrm{Se}_{2}\{\mu\right.$ -}

$\left.\left.\mathrm{C}(\mathrm{Ph})=\mathrm{CC}(\mathrm{OEt})=\mathrm{Cr}(\mathrm{CO})_{5}\right\}\right]$ (1a) in THF- $d 8$

A solution of 1a $(0.005 \mathrm{~g}, 0.006 \mathrm{mmol})$ in THF- $d 8$ $(0.7 \mathrm{~mL})$, was photolysed in a NMR tube using $400 \mathrm{~W}$ medium pressure mercury lamp for $6 \mathrm{~h}$. After photolysis, ${ }^{1} \mathrm{H}$ NMR spectrum of the reaction mixture was recorded. No signal other than those of 1a was observed.

\section{Crystal structure determination of $2 a$ and $3 c$}

Red crystals of $\mathbf{2 a}$ and $\mathbf{3 c}$ were selected and mounted with epoxy cement to glass fibres. Single crystal X-ray data were collected on Siemens P4 diffractometer by using MoK $\alpha$ radiation. The unit-cell parameters were obtained by the least-squares refinement of the angular settings of 24 reflections $\left(20^{\circ} \leq 2 \theta \leq 25^{\circ}\right)$. Pertinent crystallographic data of $\mathbf{2 a}$ and $\mathbf{3 c}$ are summarized in Table 1 . The systematic absences in the diffraction data for $\mathbf{2 a}, \mathbf{3 c}$ are uniquely consistent for the reported space groups. The structures were solved using direct methods, completed by subsequent difference Fourier syntheses and refined by full-matrix least-squares procedures. Empirical absorption corrections for 2a was applied by using program DIFABs. ${ }^{18}$ All non-hydrogen atoms were refined with anisotropic displacement coefficients and hydrogen atoms were treated as idealized contributions.

All software and sources of the scattering factors are contained in the SHELXTL (5.3) program library (G. Sheldrick, Siemens XRD, Madison, WI). Selected bond lengths and bond angles for $\mathbf{2 a}$ and $3 \mathbf{c}$ are listed in Tables 2 and 3 .

\section{Conclusion}

In Fischer carbene chemistry, the reactivity of the

Table 3. Selected bond distances $[\AA]$ and bond angles $\left[{ }^{\circ}\right]$ for $\mathbf{3 c}$

\begin{tabular}{lllc}
\hline $\mathrm{Fe}(1)-\mathrm{Fe}(2)$ & $2.550(2)$ & $\mathrm{Te}(1)-\mathrm{C}(7)$ & $2.115(8)$ \\
$\mathrm{Fe}(1)-\mathrm{Te}(1)$ & $2.518(2)$ & $\mathrm{S}-\mathrm{C}(8)$ & $1.808(8)$ \\
$\mathrm{Fe}(2)-\mathrm{S}$ & $2.243(2)$ & $\mathrm{C}(11)-\mathrm{C}(12)$ & $1.360(14)$ \\
$\mathrm{Fe}(1)-\mathrm{S}$ & $2.267(3)$ & $\mathrm{C}(9)-\mathrm{C}(14)$ & $1.435(12)$ \\
$\mathrm{Fe}(2)-\mathrm{Te}(1)$ & $2.550(2)$ & $\mathrm{C}(7)-\mathrm{C}(8)$ & $1.346(11)$ \\
$\mathrm{Fe}(2)-\mathrm{Fe}(1)-\mathrm{S}$ & $55.13(7)$ & $\mathrm{Fe}(2)-\mathrm{Te}(1)-\mathrm{C}(7)$ & $92.7(2)$ \\
$\mathrm{Fe}(1)-\mathrm{Fe}(2)-\mathrm{S}$ & $56.03(7)$ & $\mathrm{C}(16)-\mathrm{C}(7)-\mathrm{Te}(1)$ & $122.8(6)$ \\
$\mathrm{Fe}(2)-\mathrm{S}-\mathrm{Fe}(1)$ & $68.84(8)$ & $\mathrm{Fe}(1)-\mathrm{Te}(1)-\mathrm{C}(7)$ & $91.9(2)$ \\
$\mathrm{Fe}(1)-\mathrm{Te}(1)-\mathrm{Fe}(2)$ & $60.41(5)$ & $\mathrm{C}(8)-\mathrm{C}(7)-\mathrm{Te}(1)$ & $117.2(6)$ \\
$\mathrm{Fe}(1)-\mathrm{Fe}(2)-\mathrm{Te}(1)$ & $59.19(5)$ & $\mathrm{C}(9)-\mathrm{C}(8)-\mathrm{S}$ & $119.8(6)$ \\
$\mathrm{Te}(1)-\mathrm{Fe}(1)-\mathrm{Fe}(2)$ & $60.40(5)$ & $\mathrm{C}(7)-\mathrm{C}(8)-\mathrm{S}$ & $117.3(7)$ \\
$\mathrm{Te}(1)-\mathrm{Fe}(2)-\mathrm{S}$ & $82.34(7)$ & $\mathrm{C}(8)-\mathrm{S}-\mathrm{Fe}(1)$ & $107.0(3)$ \\
\hline
\end{tabular}

complexes is dominated by, among other things, the metal atom and its electron-richness or deficiency. While aryl or vinyl alkoxy carbene complexes of chromium undergo Dötz reaction (a benzannulation process that involves a CO-insertion step) under thermal conditions, CO-insertion is not observed for corresponding complexes of tungsten or amino carbene analogs of chromium. In this paper, we have reported an interesting variant where the vinyl group of a chromium carbene complex is supported on a chalcogenstabilized diiron cluster, and such substrate exhibits simultaneous operation of both the pathways-with and without the CO-insertion step during the same reaction. It is not clear at this point whether the electronic influence is restricted to the contribution by the chalcogen atoms alone, and this point needs further investigation.

Supplementary material available. Crystallographic details including complete tables of atomic coordinates, bond lengths and bond angles and anisotropic displacement parameters for $\mathbf{2 a}$ and $\mathbf{3 c}$ (10 pages).

\section{Acknowledgements}

(P. M.) would like to thank the Department of Science \& Technology, New Delhi, for a research grant.

\section{References}

1. (a) Mathur, P.; Hossain, M. M.; Umbarkar, S.; Satyanarayana, C. V. V.; Tavale, S. S.; Puranik V. G. Organometallics 1995, 14, 959. (b) Mathur, P.; Hossain, M. M. Organometallics 1993, 12, 2398. (c) Mathur, P.; Dash, A. K.; Hossain, M. M.; Umbarkar, S.; Satyanarayana, C. V. V.; Chen, Y.-S.; Holt, E.; Rao, S. N.; Soriano, M. Organometallics 1996, 15, 1356.

2. (a) Mathur, P.; Ghosh, S.; Sarkar, A.; Satyanarayana, C. V. V.; Rheingold, A. L.; Liable-Sands, L. M. Organometallics 1997, 16, 3536. (b) Mathur, P.; Ghosh, S.; Sarkar, A.; Satyanarayana, C. V. V.; Puranik, V. G. Organometallics 1997, 16, 4392.

3. Mathur, P.; Ghosh, S.; Sarkar, A.; Satyanarayana, C. V. V.; Drake, J. E.; Yang, J. Organometallics 1997, 16, 6028.

4. Grotjahn, D. B.; Dötz, K. H. Synlett 1991, 381.

5. Mathur, P.; Ghosh, S.; Sarkar, A.; Rheingold, A. L.; Guzei, I. A. Organometallics 1998, 17, 770. (b) Mathur, P.; Ghosh, S.; Sarkar, A.; Rheingold, A. L.; Guzei, I. A. J. Organomet. Chem. 1998, 566, 159.

6. Philip, R.; Ravindrakumar, G.; Mathur, P.; Ghosh, S. Chem. Phys. Lett. 1999, 313, 719.

7. Yamashita, A. Tetrahedron Lett. 1986, 27, 5915.

8. Mathur, P.; Hossain, M. M. Organometallics 1993, 12, 2398.

9. (a) Larock, C. K.; Leach, D. R.; Bijorge, S. M. Tetrahedron Lett. 1982, 23, 715. (b) Fuchita, Y.; Hiraki, K.; Yamaguchi, T.; Maruta, T. J. Chem. Soc. Dalton Trans. 1981, 2405. (c) Alper, H. J. Organomet. Chem. 1974, 80, C29. (d) Alper, H. J. Organomet. Chem. 1974, 73, 359.

10. (a) Wulff, W. D. In Comprehensive Organic Synthesis; Trost, B. M., Fleming, I., Eds.; Pergamon: New York, 1991; Vol. 5. (b) Wulff, W. D. In Advances In Metal-Organic Chemistry; Liebeskind, L. S., Ed.; JAI: Greenwich, CT, 1989; Vol.1. (c) Dötz, K. H.; Fischer, H.; Hofmann, P.; Kreissel, F. R.; Schubert, U.; Weiss, K. Transition Metal Carbene Complexes; Verlag 
Chemie: Deerfield Beach, FL, 1984. (d) Dötz, K. H. Angew. Chem., Int. Ed. Engl. 1984, 23, 587.

11. Wulff, W. D. In Comprehensive Organometallic Chemistry, Abel, E. W., Stone, F. G. A., Wilkinson, G., Hegedus, L. S., Eds.; Pergamon: UK, 1995; Vol. 12, p 12.

12. Xu, Y.-C.; Wulff, W. D. J. Org. Chem. 1987, 52, 3263.

13. (a) Merlic, C. A.; Roberts, W. M. Tetrahedron. Lett. 1993, 34, 7379. (b) Merlic, C. A.; Burns, E. E. Tetrahedron. Lett. 1993, 34 , 5401. (c) Merlic, C. A.; Burns, E. E.; Xu, D.; Chen, S. Y. J. Am. Chem. Soc. 1992, 114, 8722. (d) Merlic, C. A.; Xu, D. J. Am. Chem. Soc. 1991, 113, 7418.
14. Mathur, P.; Chakrabarty, D.; Hossain, M. M.; Rashid, R. S.; Rugmini, V.; Rheingold, A. L. Inorg. Chem. 1992, 31, 1106.

15. Mathur, P.; Sekar, P.; Satyanarayana, C. V. V.; Mahon, M. F. Organometallics 1995, 14, 2115.

16. Mathur, P.; Chakrabarty, D.; Hossain, M. M.; Rashid, R. S. J. Organomet. Chem. 1991, 420, 79.

17. Fischer, E. O.; Kreissl, F. R. J. Organomet. Chem. 1972, 35, C47-C51.

18. Walker, N.; Stuart, D. Acta Crystallogr. A 1983, 39, 158. 